\section{Guineaorm - siste steg mot utryddelse?}

\author{
I januar 2013 ble det ikke rapportert et eneste tilfelle av guineaorm \\ til WHO. Det er en historisk begivenhet.
}

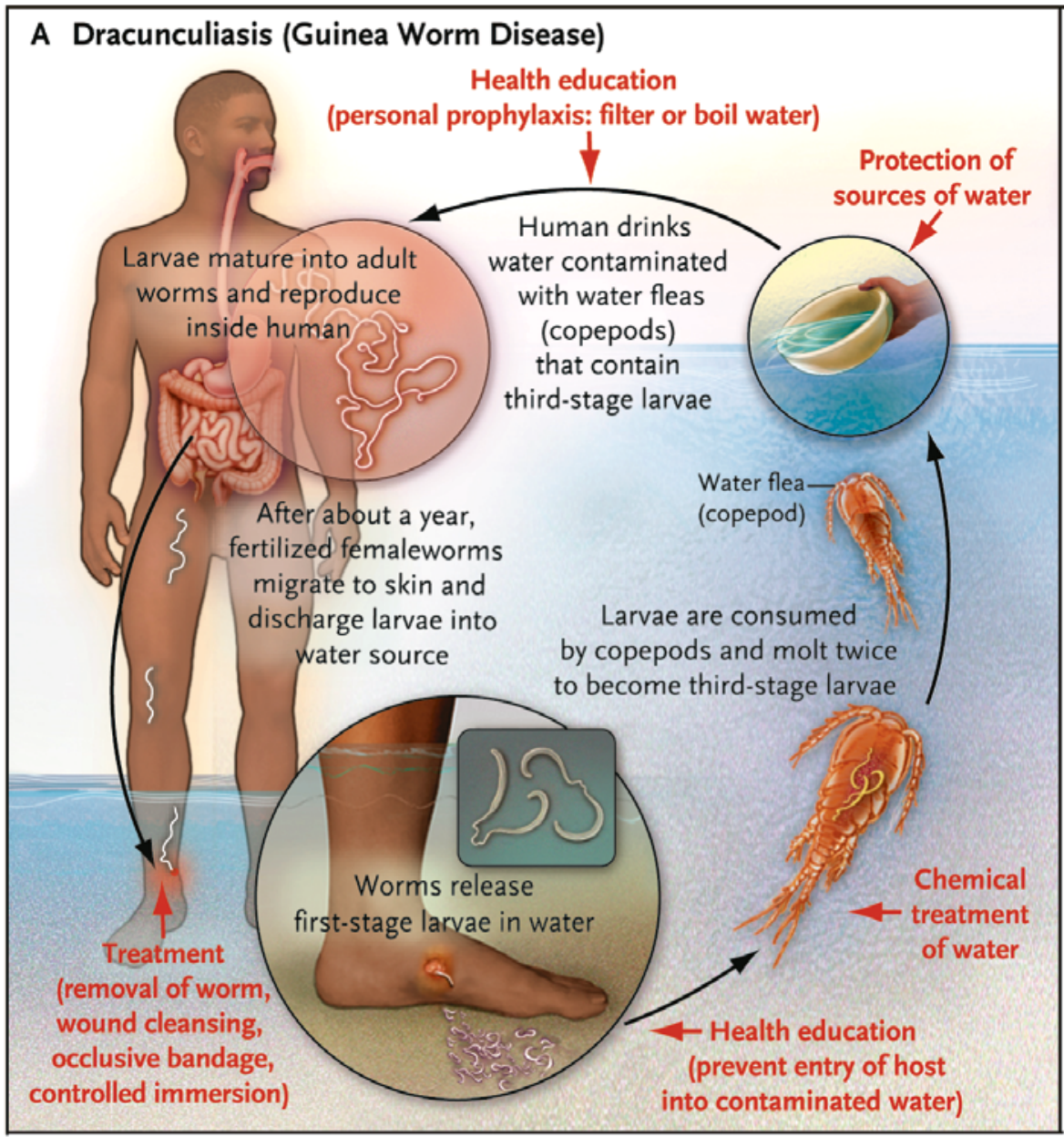

Guineaormens livssyklus og tiltak for utryddelse av sykdommen (1). Gjengitt med tillatelse fra New England Journal of Medicine

Den neglisjerte tropesykdommen guineaorm (dracunculiasis) skyldes infeksjon med parasitten Dracunculus medinensis. Omtrent ett år etter at en person har drukket vann som inneholder parasitten, begynner ormen å krype ut gjennom huden (1). I 1980 startet en global kampanje for å utrydde sykdommen. Tiltakene har bl.a. bestått i helseopplysning, rent vann til befolkningen, behandling og frivillig isolering av pasienter. Mens det var 3,5 millioner estimerte tilfeller i 20 afrikanske og asiatiske land i 1986 (1), ble det kun rapportert om 542 tilfeller til WHO i 2012 (2). De fleste tilfellene rapporteres fra Sør-Sudan der politisk ustabilitet har forsinket arbeidet. Det har også vært spredte tilfeller i Mali, Tchad og Etiopia. I januar 2013 var det for første gang ingen innrapporterte tilfeller (2).

- Etter at Jimmy Carter og andre har engasjert seg i kampen mot sykdommen, har det siden 1990 vært en dramatisk reduksjon i antall tilfeller, sier professor Bjørn Myrvang ved Kompetansesenter for import- og tropesykdommer, Oslo universitetssykehus.

- Det er selvsagt gledelig at det ikke er rapportert nye tilfeller i løpet av en måned, men situasjonen i Sør-Sudan er slik at det er rimelig å tro at det fortsatt vil bli rapportert nye tilfeller derfra, avslutter Myrvang.

\section{Kristine Lillebø}

kristinelillebo@gmail.com

Kompetansesenter for import- og tropesykdommer Infeksjonsmedisinsk avdeling Ullevål

Oslo universitetssykehus

\section{Litteratur}

1. Hopkins DR. Disease eradication. N Engl J Med 2013; 368: 54-63

2. WHO. Monthly report on dracunculiasis cases, January 2013 - first month with zero cases. Wkly Epidemiol Rec 2013; 88: 128.

\section{Kirurgisk forskning er best i medisinske tidsskrifter}

\author{
Kirurgiske randomiserte studier \\ rapporteres med høyere kvalitet \\ i medisinske tidsskrifter enn \\ i kirurgiske.
}

En gruppe nederlandske forskere har analysert 327 randomiserte studier med kirurgiske intervensjoner i årene 2007-12 (1). De vurderte om studiene var registrert som kliniske forsøk før oppstart, om de publiserte endepunktene var i samsvar med registrering i protokollene og om det ved endring av endepunktene oftere ble signifikante funn.

I 75 av 152 studier (49\%) fant man avvik mellom registrerte og publiserte endepunkter, oftest i form av nytt primært endepunkt eller utelatt primært endepunkt i publikasjonen. Endring av endepunkter ga oftere signifikante funn og var hyppigere dersom de kirurgiske studiene sto på trykk i kirurgiske tidsskrifter (61\% mot $41 \%$ i medisinske tidsskrifter). Andelen studier som var registrert i databaser for kliniske forsøk, var langt høyere for studier publisert i medisinske tidsskrifter (98\%) enn i kirurgiske tidsskrifter (49\%).

- Det er nedslående og skremmende at manipulasjon med endepunkter er så vanlig, selv i randomiserte studier. En tilslørt eksplorativ statistisk tilnærming på jakt etter signifikans er spesielt problematisk og uetisk i intervensjonsstudier. Randomiserte studier i kirurgi er dessuten mangelvare og blir sjeldnere gjentatt enn medikamentstudier. Enkeltstudier blir ofte retningsgivende for behandling, sier overlege Ole Solheim ved Nevrokirurgisk avdeling, St. Olavs hospital og forsker ved Nasjonalt kompetansesenter for ultralyd og bildeveiledet behandling. Han mener tidsskriftene må ta ansvar.

- Rapporteringsskjevheter er et stort problem både for kirurgiske studier og medikamentstudier. Siden manglende registrering av protokoll og avvik mellom protokoll og endelig produkt er lett synlig, er dette noe tidsskriftredaksjonene har et tungt ansvar for å rydde opp i, sier Solheim.

\section{Ole Kristian Losvik \\ losvik@gmail.com}

St. Olavs hospital

\section{Litteratur}

1. Hannink G, Gooszen HG, Rovers MM. Comparison of registered and published primary outcomes in randomized clinical trials of surgical interventions. Ann Surg 2013; 257: 818-23. 